\title{
Pulp-Dentin Tissue Healing Response: A Discussion of Current Biomedical Approaches
}

\author{
Dishant Shah ${ }^{1}$, Tyler Lynd ${ }^{1}$, Donald Ho ${ }^{1}$, Jun Chen ${ }^{1}$, Jeremy Vines ${ }^{1}$, Hwi-Dong Jung ${ }^{2}{ }^{\mathbb{C}}$, \\ Ji-Hun Kim ${ }^{3}$, Ping Zhang ${ }^{4}$, Hui Wu ${ }^{4}$, Ho-Wook Jun ${ }^{1}$ and Kyounga Cheon ${ }^{4, * \mathbb{D}}$ \\ 1 Department of Biomedical Engineering, University of Alabama at Birmingham, 1825 University Blvd, \\ Birmingham, AL 35294, USA; Dshah9542@gmail.com (D.S.); tlynd@uab.edu (T.L.); \\ donaldho@uab.edu (D.H.); cj1016@uab.edu (J.C.); jbvines@gmail.com (J.V.); hwjun@uab.edu (H.-W.J.) \\ 2 Department of Oral \& Maxillofacial Surgery College of Dentistry, Yonsei University, 50-1 Yonsei-Ro, \\ Seodeamun-Gu, Seoul 03722, Korea; cancer7@yuhs.ac \\ 3 Department of Dentistry, Wonju College of Medicine, Yonsei University, 20 Il-San-ro, Wonju, \\ Gangwon-Do 26426, Korea; pedo@yonsei.ac.kr \\ 4 Department of Pediatric Dentistry, University of Alabama at Birmingham, 1919 7th Avenue S, Birmingham, \\ AL 35294, USA; pingz@uab.edu (P.Z.); hwu@uab.edu (H.W.) \\ * Correspondence: kcheon@uab.edu; Tel.: +1-205-975-4303
}

Received: 18 December 2019; Accepted: 31 January 2020; Published: 5 February 2020

check for updates

\begin{abstract}
Dental pulp tissue exposed to mechanical trauma or cariogenic process results in root canal and/or periapical infections, and conventionally treated with root canal procedures. The more recent regenerative endodontic procedure intends to achieve effective root canal disinfection and adequate pulp-dentin tissue regeneration; however, numerous limitations are reported. Because tooth is composed of vital soft pulp enclosed by the mineralized hard tissue in a highly organized structure, complete pulp-dentin tissue regeneration has been challenging to achieve. In consideration of the limitations and unique dental anatomy, it is important to understand the healing and repair processes through inflammatory-proliferative-remodeling phase transformations of pulp-dentin tissue. Upon cause by infectious and mechanical stimuli, the innate defense mechanism is initiated by resident pulp cells including immune cells through chemical signaling. After the expansion of infection and damage to resident pulp-dentin cells, consequent chemical signaling induces pluripotent mesenchymal stem cells (MSCs) to migrate to the injury site to perform the tissue regeneration process. Additionally, innovative biomaterials are necessary to facilitate the immune response and pulp-dentin tissue regeneration roles of MSCs. This review highlights current approaches of pulp-dentin tissue healing process and suggests potential biomedical perspective of the pulp-dentin tissue regeneration.
\end{abstract}

Keywords: pulp-dentin tissue; inflammatory response; immune cells; mesenchymal stem cells; chemical signaling; biomaterials; tissue regeneration; nitric oxide

\section{Introduction}

Dental infection is demonstrated as a bacteria mediated destruction of periapical tissue, including dental pulp, apex, and periodontium, accompanied by pain, swelling, mobility, and abscess formation [1]. Dental infection or periapical abscess with pulpal necrosis is the consequence of trauma; untreated/ mistreated dental caries; failed dental root canal treatment; as well as genetics, syndromes, and immune-associated medicament uses [2]. Clinically, untreated dental caries progresses to dental abscess and leads to tooth loss in $71 \%$ of adults age 45 to 64 [3]. Currently, dental abscesses of varying severity are treated using traditional root canal treatment. In young patients, tooth abscess with immature root (open apex, Figure 1A) can be treated with the regenerative endodontic procedure (REP) 
as one of the treatment options [4]. The REP is described as a "biologically-based procedure designed to replace damaged structures of pulp-dentin complex" using a blood clot mediated tissue healing strategy [5]. The REP aims to restore pulpal function and complete root development [6,7]. Despite some favorable clinical outcomes, the failure rate for the REP reaches 39\% at 2-year follow ups [8]. Adverse results include tooth discoloration [9-11], root fracture [12-15], bone-like, and cementum-like periodontal tissue replacement in pulp tissues [16-21], and uncontrolled intra-canal medicament dose affecting apical stem cells [11]. Still, the revascularization capacity [22] and transplanted stem cell logistics (resources, required amount, transplantation, and immune responses) remain relevant concerns for the REP [23-25]. In addition, 79\% of the failed treatments were attributed to persistent infection after the REP [8].

To overcome the current unsolved problems of pulp-dentin tissue regeneration, dental tissue engineering has adopted the use of various sources of stem cells, scaffold systems, and growth factors [26-28]. When pulp-dentin tissue is exposed to trauma or bacterial infection, regardless of the acute or chronic stages, odontoblasts recognize pathogenic signals and initiate the localized innate healing response [29,30]. The odontoblasts are positioned to enable its cell body to reach into the pulp-dentin interface and embed its long processes in the dentinal tubules as a pulp-dentin tissue defense line (Figure 1A). However, after exposure to severe bacterial penetration, there is a significant depletion of resident odontoblasts at the pulp-dentin interface, and subsequently, a release of inflammatory markers and cytokines [30]. Moreover, pulp-dentin tissue revitalization considers the aspect of wound healing involving the interactions among pulp-dentin cells (odontoblasts, mesenchymal stem cells (MSCs), immune cells, and neurovascular cells) and its chemical signaling by release of cytokines, chemokines, and other soluble factors (Figure 1B).

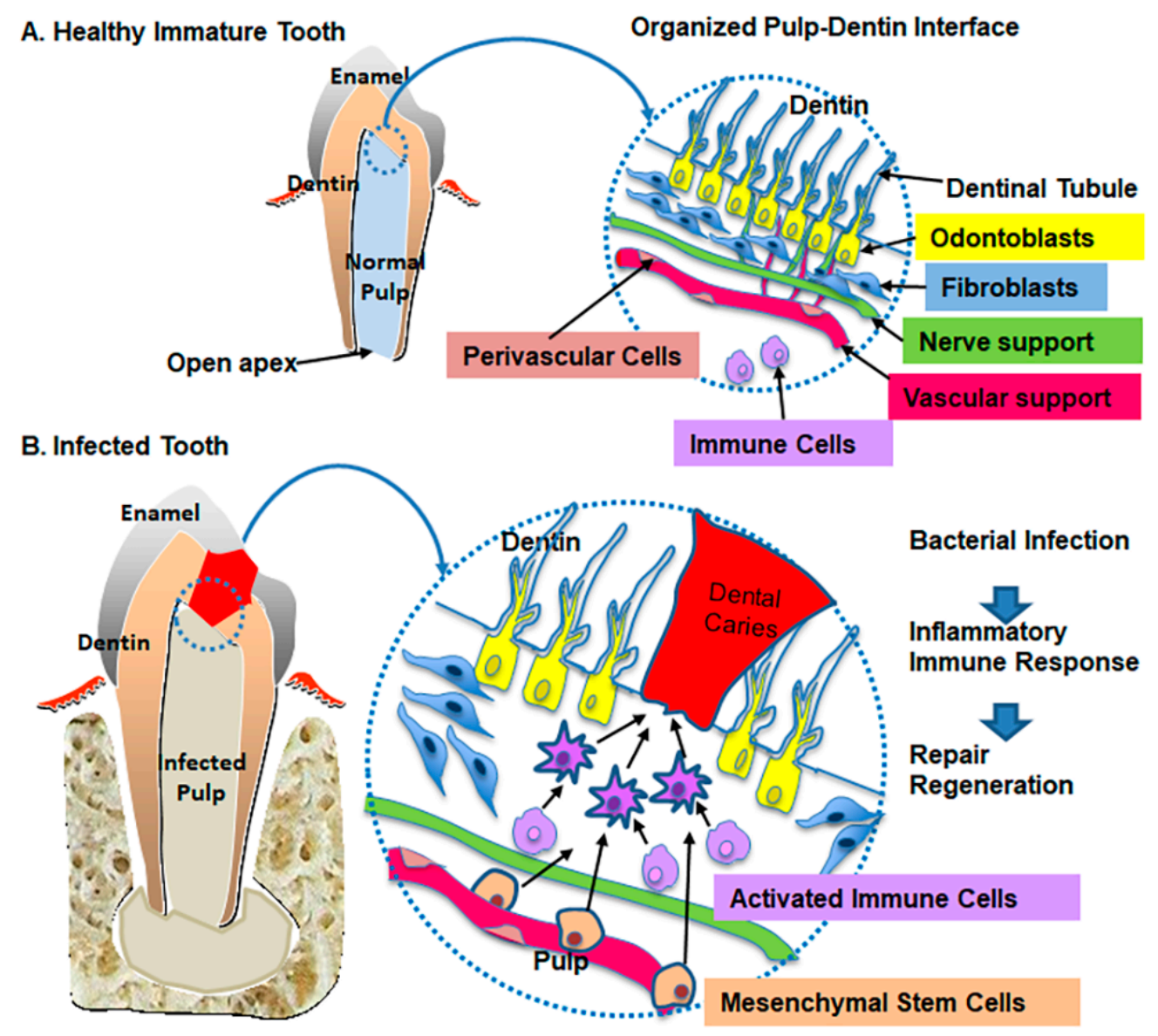

Figure 1. Cellular response at pulp-dentin interface: (A) Healthy immature tooth. (B) Infected tooth. 
This review will discuss the inflammatory response on the pulp-dentin interface, which is essential for the subsequent healing and repair process. Throughout the numerous dental tissue engineering approaches, the pulp-dentin tissue interface is known to be the primary healing process. Depending on the depth of caries or bacterial penetration, the healing interface could be the line of defense and found as multiple loci from the coronal part to the root apex in any area of pulp-dentin tissue.

\section{Characteristics of Pulp-Dentin Tissue}

Normal pulp tissue is composed of organized cell layers that proliferate and differentiate to complete the root formation [31]. The pulp is mesenchymal soft tissue originating from the neural crest and extends from the central chamber to the root apex. Structurally, the pulp is loose connective tissue composed of pulp cells, collagen fibers, extracellular matrix, nerves, and blood vessels. The healthy dental pulp contains a heterogeneous mixture of cells including odontoblasts, fibroblasts, immune cells (macrophages/histiocytes, dendritic cells, and T-lymphocytes), Schwann's cells, and vascular/perivascular cells [32]. The pulp cells are responsible for tissue repair and self-renewal along with the prepositioned inflammatory process [33]. Depending on the intensity and infiltration depth of the bacterial invasion, viable pulp cells are able to initiate the repair process with an inflammatory reaction.

During root dentin development, Hertwig's epithelial root sheath (HERS) presents as a merged inner- and outer-enamel epithelial structure from the cervical loop of the enamel organ surrounding the root surfaces. The HERS then proliferates towards the distal end and bends at a near 45 degree angle forming an epithelial diaphragm which determines the number, shape, and size of the root [34]. HERS plays a critical role for root dentin and cementum formation in conjunction with dental papilla [35]. Progressing root development, odontoblasts produce dentin layers deposited at the pulp-dentin interface and retreat toward the root apex (apical papilla) during the early stage of root development. In the later stage of root development, the apical papilla reserves undifferentiated MSCs as a potential source of root dentin formation [36]. Along with the HERS, stem cells from apical papilla (SCAP) and follicular tissue are implicated in developing apical complex cells to establish the root and periodontium: root dentin, cementum, and the periodontal ligament [37,38].

However, after exposure to infection, the pulp-dentin interface of root structures, including radicular pulp, apical papilla, and HERS, show significant histopathologic alterations devoid of cellular components (odontoblasts and MSCs) and misplacement of cementum-like, osteo-like, periodontal ligament-like tissue $[35,39,40]$. The affected root canal wall is free from odontoblasts and repaired by the deposition of periodontal tissue without normal dentin structures such as odontoblasts' processes and dentinal tubules. When the pulp tissue progresses into the necrotic phase, apical papilla demonstrate extremely reduced cellularity with a discontinuous or absent HERS [35,40].

The tooth structure is composed of inner non-mineralized pulp tissue, one directional neurovascular supply, and surrounding mineralized dentin. Due to the dental pulp being confined by mineralized tissue, the initial inflammatory/immunological reaction increases intra-canal pressure, and the pressure extends toward the root apex down the root canal, causing periapical abscess [35,41,42]. Left untreated, the abscess can cause root resorption and periodontal tissue disruption involving the periodontal ligament space and surrounding alveolar bone and result in the loss of bony support and teeth extrusion [42,43]. Therefore, the root canal treatment (endodontic therapy) intends to remove infected tissue to decrease intra-canal pressure from the dental pulp and alleviate pain [39,41]. The pulp treatment modality is decided based upon the penetration depth of the inflammation and maturity of the root apex as indicated in direct or indirect pulp capping, partial or complete pulpectomy, apexification, or apexogenesis $[39,44,45]$. Withstanding the pathological challenges, pulp-dentin-periodontium tissue will respond and engage in a biological defense mechanism via cell-cell communication and chemical signaling, which could function as the healing foci of repair/regeneration. 


\section{Biologic Defense Mechanism on Pulp-Dentin Tissue}

Odontoblasts-dentin-producing cells-have been shown to sense bacterial pathogens at the pulp-dentin interface and respond to them by releasing proinflammatory cytokines and antibacterial agents such as nitric oxide (NO) $[29,30,46]$. NO is produced as part of the host defense in a nonspecific immune reaction [47]. When any pathogen bypasses the pulp-dentin interface, either by degrading the dentin or penetrating through dentin tubules, the odontoblast releases chemokines to recruit immune cells (e.g., dendritic cells (DC) and macrophages) to the infected locus [48]. Upon binding to the antigens, the immature DC will mature and influence the innate and adaptive immunity process. DCs migrate to lymph nodes where the antigens will be released to naïve CD4+ T cells, which will then differentiate to either regulatory T cells or effector CD4+ T helper cells (Th1 or Th2), depending on the cytokines present $[49,50]$. Th1 and Th2 influence macrophage activity and enable immune mechanisms specific to which $\mathrm{T}$ helper cell was produced.

Macrophages serve to phagocytose invading pathogens and can be activated by Th1 and inhibited by Th2 [51]. Macrophages are known as one of the critical mediators to influence the innate immune response [30,52]. A macrophage begins at the resting $\mathrm{M} 0$ state, and the cell can be polarized to a proinflammatory M1 state or an anti-inflammatory M2 state. Polarization to the M2 macrophage fosters tissue repair and inflammation resolution. The wound healing process begins with an initiated proinflammatory phase and transitions to anti-inflammatory phases, which corresponds with macrophage phenotypic alterations from M1 to M2 respectively along the release of the proand anti-inflammatory cytokine. The pleotropic macrophages are devoted in many stages of the wound healing process including promotion of inflammation, reparation with anti-inflammation, and synthesis of extracellular matrix (ECM) [52]. In addition, natural killer cells and natural killer T cells are other innate immune system components and are present in normal dental coronal pulp tissue as a first line of defense. Natural killer T cells support the development of Th1 and Th2 immune responses of destroying infiltrating pathogens [53]. Through the progression of dental caries and inflammation, the number of B lymphocytes are increased and associated with the modulation of DC functions [54]. Of all the leukocytes present in human dental pulp, $21 \%$ are cytotoxic CD $8+\mathrm{T}$ cells, $11 \%$ are CD4+ $\mathrm{T}$ cells, and $4 \%$ are DCs. Importantly, the endothelium-derived NO modulates leukocyte adherence in vessel walls [55]. This characterization of the leukocyte population can give a glimpse into the initial ability of the pulp to defend itself before more leukocytes are brought towards the pulp by the circulatory system [30].

A current study reports that inflammatory responses are prerequisite and can stimulate dental tissue repair responses [56]. When the pulp is exposed to caries, bacteria, or dental filling materials, the pulp-dentin interface undergoes a mild to severe inflammatory process. The proinflammatory cytokines, tumor necrosis factor alpha (TNF- $\alpha$ ), interferon gamma (IFN- $\gamma$ ), interleukin 1beta (IL-1 $\beta$ ), IL-6, etc. are initiated to promote the host immune response, whereas the anti-inflammatory cytokines, steroids, transforming growth factor beta (TGF- $\beta$ ), IL-10, NO, etc. are released to limit the tissue damage. With the interactive balance between the pro- and anti-inflammatory signaling, pulp-dentin tissue can respond with cell necrosis, bone resorption, pulp calcification, or revascularization. Low levels of inflammatory cytokine signals direct the response of the cells to drive differentiation and mineralization to favor healing, whereas a high level of inflammatory cytokine signaling may result in the recruitment of more immune cells further accelerating the inflammatory response in vitro [56]. For instance, chemokine receptor 4 (CXCR4) appears to have both proinflammatory and repair processes. CXCR is critical for lymphocyte trafficking as well as hematopoiesis with organogenesis in conjunction with stromal cell derived factor-1 [57]. Nuclear Factor kappa-light-chain-enhancer of activated B cells (NF-KB) and p38 mitogen-activated protein kinase (MAPK) are key signaling pathways in both the proinflammatory and healing responses [58]. Notably, low levels of cytokine secretion causes mesenchymal stem cells to perform healing associated immunomodulatory and anti-inflammatory functions; however, a high level of cytokine secretion may hinder the response from the stem cells $[57,59,60]$. 
While the inflammatory phase of pulp-dentin tissue progresses, the cellular proliferation and differentiation phases are necessary for the wound healing/repair process $[30,61]$. During the process, vascularization is critical for the provision of nutrition and oxygen as well as the elimination of metabolic waste. Furthermore, the vascularization could guide MSCs migration from perivascular region to the inflammatory loci [62]. Having multipotential and self-renewal properties, MSCs such as dental pulp stem cells (DPSCs) differentiate into odontoblasts, fibroblasts, endothelial cells, and neural cells [63-68]. The vascularization is supported by the angiogenic signaling molecules, vascular endothelial growth factor (VEGF), basic fibroblast growth factor (bFGF), and TGF- $\beta$ which are released from injured pulp cells, endothelial cells, and ECM $[69,70]$. Collectively, the inflammatory, proliferation, and differentiation phases collaborate to enrich a natural healing process for pulp-dentin tissue.

\section{Mesenchymal Stem Cell Response and Pulp-Dentin Tissue Response}

Stem cells possess the ability of self-renewal and pluripotency resulting in the capacity to differentiate into a variety of cell types [71]. Stem cells can be classified into three types: (1) Embryonic stem cells, which are obtained from the inner cell mass of blastocysts. Embryonic stem cells have been harvested from mice and humans; however, the actual application has been restricted due to the ethical concerns and obtaining difficulty [72]. (2) Induced pluripotent stem cells (iPSCs), which are obtained from the overexpressed growth factor treated adult cells. iPSCs are similar to embryonic stem cells at a cellular level in their ability for differentiation and self-renewal [73]. iPSCs have been harvested from fibroblasts, however, their genetic stability is still questionable [71]. (3) MSCs originate from mesoderm and possess genetic stability. Human MSCs have been isolated from a variety of sources in the human body such as bone marrow, skin, perivascular tissues, as well as the dental tissues [25,74-76]. Recent studies demonstrated that MSCs isolated from dental tissue may serve as a more feasible and beneficial source for the MSC-based cell therapy over bone marrow derived MSCs [77].

MSCs has been studied to perform a major role in tooth growth and repair by responding to biological stimulations and signals [78]. Depending on the depth of penetration of dental caries from dentin to pulp, an innate defense mechanism is initiated by the odontoblast, which produces a reactionary dentin layer in response to the stimulus. However, resident odontoblasts will be severely damaged by the extension of the penetration. Consequently, dental MSCs, predominantly DPSCs, reserve the capacity to migrate to the site of injury and differentiate into odontoblasts to commence reparative dentin synthesis for tissue recovery. Evidence suggests dental MSCs develop from both pericytes and differentiate into odontoblast during growth and in response to odontoblast damage [79]. DPSC differentiation is associated with the release of sequestered TGF- $\beta$ following physical damage and Wnt signaling. As a result, the presence of TGF- $\beta$ in dentin tubules assists in reparative dentin formation. The beta-catenin-dependent Wnt signaling pathway is stimulated upon injury and plays a fundamental role in dental MSC deployment [80]. In these studies, DPSCs have exhibited great potential to reestablish pulp-like tissue enhancing the conventional root canal treatment, which lack the ability to restore pulp vitality [78]. In addition, the immune modulatory effects of DPSCs are demonstrated by the association of immune cell proliferation and tissue inflammation suppression during the repair phase $[78,81]$. MSCs can promote the activation of macrophages transition from proinflammatory M1 to anti-inflammatory M2 phenotypes; therefore, MSCs are responsible for the regulation of inflammatory reactions through the secretion of cytokines, chemokines, and other factors to maintain body homeostasis and wound healing process [82,83]. By the evidenced immune-modulatory role, DPSCs are critical cells to repair the pulp-dentin tissue and restore tooth function. Therefore, genuine pulp-dentin regeneration using DPSCs is highly expected using an innovative biomedical approach in the near future.

\section{Dental Apex and Periodontal-Tissue Response}

Dental infection that progresses and reaches the periapical and periodontal interface by extended pathology as a periodontal abscess can be classified as either marginal periodontitis or apical 
periodontitis. Both forms of periodontitis lead to the destruction of surrounding dentin, cementum, periodontal ligament (PDL), alveolar bone, and gingival tissue [84]. During the pathologic process, the host's innate and adaptive immune cells indirectly mediate the destruction of the periodontal tissues via inflammatory responses [85,86]. Guided tissue regeneration (GTR) following periapical surgery improves healing for the damaged and lost tissue by using autogenous cells from healthy tissue including alveolar bone, PDL, and cementum $[84,87,88]$. However, GTR treatments have been incapable of fostering complete and functional periodontal tissue regeneration including the proper composition of peri-apex, cementum, PDL, and alveolar bone. Rather, the treatment results in a collection of undesired fibrous connective tissue, cellular cementum, and bone tissue [84]. Although the regenerative medicine-based procedure implicates great potential, the clinical outcomes and prognoses remain in concern due to unpredictability [89]. Severity of infection and implanted biomaterials affect periapical wound healing resulting in inflammation, fibrosis, and periodontal destruction [90]. Therefore, periodontal wound healing depends on controlling and modulating the inflammatory cytokine response leading to therapeutic regeneration outcomes [91].

\section{Nitric Oxide (NO) and Pulp-Dentin Tissue Response}

Nitric oxide (NO), a short-lived radical and inert gas, reserves a vital function in regulating inflammatory response in wound repair. Innate NO is produced by immune and non-immune cells by nitric oxide synthase (NOS) via L-arginine metabolism. Among the known three isoforms, endothelial NOS (eNOS) and neuronal NOS (nNOS) are constitutively expressed and produce NO at a constant basal level. Inducible NOS (iNOS) is demonstrated using cytokines, growth factors, and inflammatory stimuli on target cells in the early phase of the inflammation and yields much greater levels of NO than the constitutive isoforms of eNOS and nNOS [92].

As shown in the Figure 2, NO's bioactive functions are explored and demonstrated [93]: NO is known as a neurotransmitter to mediate vasodilator tone, respiratory, genitourinary tract, and cardiac functions via activation of the cyclic guanosine monophosphate (c-GMP) [47]. NO significantly contributes to promote angiogenesis and develop mature blood vessels via recruiting perivascular and endothelial cells [94]. NO has also been shown to affect vascular endothelial growth factor (VEGF) release during angiogenesis occurring in bone remodeling [95]. Furthermore, NO reserves the ability to either inhibit the growth or directly eliminate bacteria and prevent infection. However, the molecule has an elevated risk for toxicity by direct application. Therefore, the use of biomaterials to mediate its release is important to ensure the viability of surrounding tissue [96]. NO has been implicated in the modulation of tumor biology with both tumoricidal and tumor-promoting properties. The compound can encourage tumorigenesis in cells responsive to its angiogenic and antiapoptotic roles. In contrast, $\mathrm{NO}$ is often cytostatic in tumors due to the suppression of DNA synthesis via the salvage pathway and the regulation of aconitase and ribonucleotide reductase. The tumor suppressing properties are augmented at elevated levels of $\mathrm{NO}$ [97].

Additionally, NO coordinates key processes for tissue repair at moderate levels including collagen synthesis, cell proliferation, and cellular differentiation [92]. NO derived from eNOS in bone was found to show effects on bone formation in vivo, demonstrated by compelling evidence that eNOS knockout mice exhibited large insufficiencies in bone formation [98]. A recent study reported that rat dental pulp stem cells (rDPSCs) stimulated by exogenous NO could transform into odontoblast-like cells with enhanced alkaline phosphatase (ALP) activity and expression levels of odontoblast-specific genes such as runt related factor 2 (Runx2), DMP 1, and dentin sialophosphoprotein through the NF-kB pathway, highlighting promising therapeutic possibilities for NO treatment in the clinic [99]. 


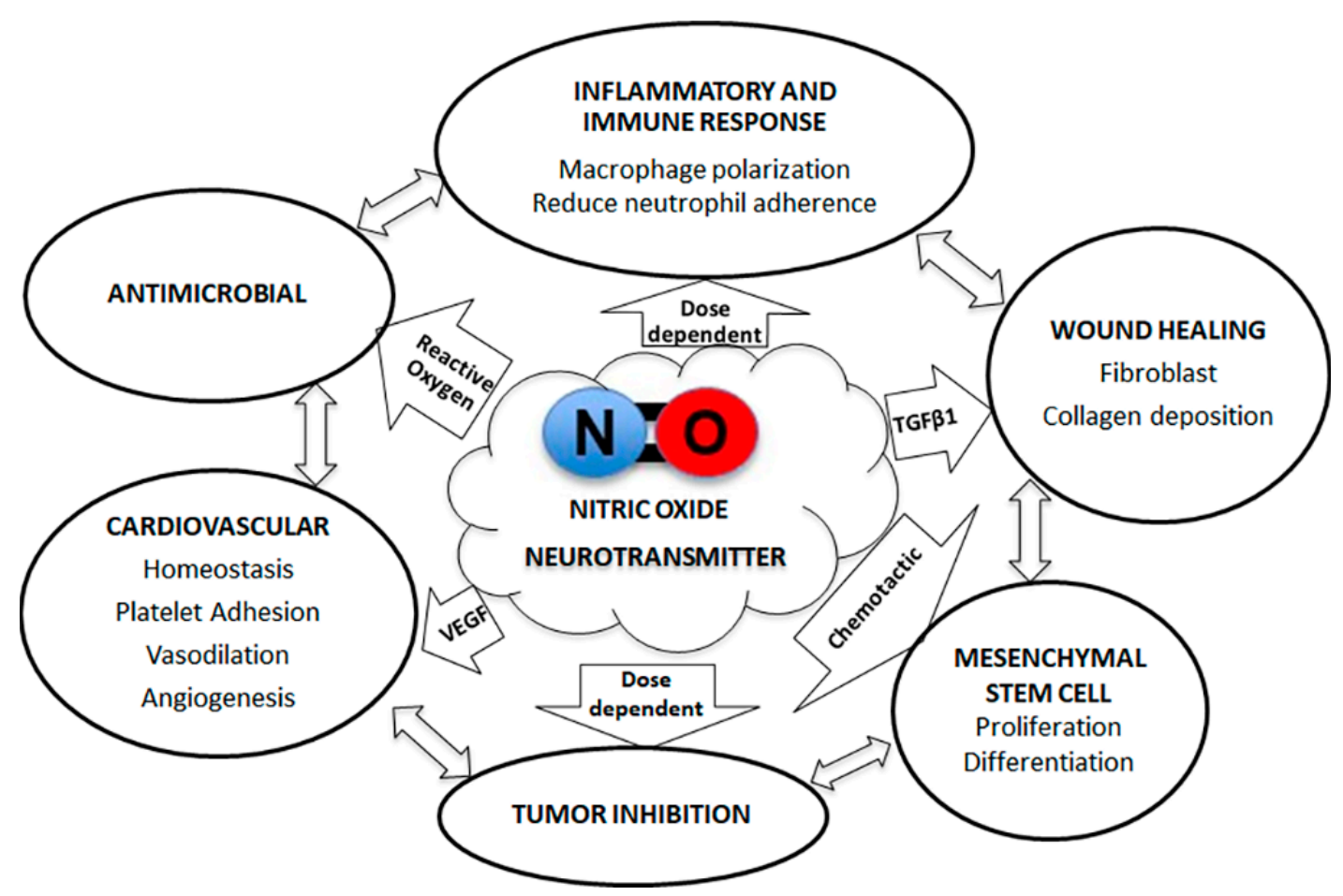

Figure 2. Multifunctional effects of nitric oxide for potential tissue regeneration.

Furthermore, $\mathrm{NO}$ is known to contribute to the immune response and wound healing process by its antibacterial capacity and regulatory effect on immune cell activation and polarization [100-102]. NO may be associated with macrophage polarization. One study describes the role of iNOS in the suppression of M1 macrophage polarization and found NO modified tyrosine residues via nitration in Interferon regulatory factor 5, a key transcription factor for M1 macrophage polarization [101]. Likewise, an additional study confirms the effects of NO on the suppression of M1 macrophage polarization and suggests that NO encourages M2 polarization [102]. The findings highlight the immunomodulatory potential of NO to promote pulp-dentin tissue wound healing.

NO plays an important biphasic role in the function of osteoblasts and osteoclasts. Osteoblasts and osteoclasts are the two major cell types responsible for bone formation and resorption, respectively. The effect of $\mathrm{NO}$ on osteoblasts in vitro has been reported to be associated with the concentration of NO present in the local bone microenvironment [47]. High NO concentrations with rapid release cause proinflammatory reactions, which inhibit proliferation and differentiation and induce an apoptosis effect on osteoblasts and osteoclasts [103]. Although low NO concentrations enhanced osteoblast growth, cytokine production, and survival [104], a study demonstrates that a low concentration of NO will stimulate the $\mathrm{Wnt} / \beta$-catenin pathway and increase osteogenic differentiation genes such as ALP, osteocalcin, collagen-1, and Runx2 [105]. An in vivo study demonstrated that a low dose of NO corresponds with an increasing number of osteoblasts, mineral apposition, and bone formation rates via angiogenesis in endochondral ossification and bone repair [105,106]. Therefore, NO releasing biomaterials may play important roles in pulp-dentin tissue regeneration.

\section{Consideration of Potential Biomaterials for the Pulp-Dentin Tissue Revitalization}

The foundation of reliable pulp-dentin tissue regeneration depends on pulp ECM tissue mimicking scaffolds, characterized as bioactive, antibacterial, and anti-inflammatory materials with a low immunogenic response and a high therapeutic drug delivery efficacy [107]. In addition, scaffolds possess biocompatibility to allow cell adhesion, proliferation, differentiation, as well as migration [108,109]. Clinically, materials for scaffolds need to be injectable, adaptable, biodegradable, and capable of gradually releasing growth factors [110]. A series of natural and synthetic polymers have been reported 
as a potential scaffold to substitute the soft, functional pulp tissue ECM [109,111,112]. Natural polymers provide a more natural ECM environment and limited toxicity compared to synthetic polymers. Synthetic polymers increase feasibilities of scaffold characteristics [113]. Among natural polymer scaffolds, collagen is one of the most widely used biomaterials. The natural collagen motifs give rise to its cell adhesive and biocompatible properties. Studies have shown that collagen hydrogels encourage angiogenesis, adipogenesis, and osteogenesis. Collagen hydrogels restricted mechanical property could be modified using crosslinking method; however, the attempts indicate limited success. Furthermore, batch-to-batch variation and pathogen transmission are common concerns for natural scaffolds $[114,115]$. Chitosan is another promising natural biomaterial for endodontic treatment. The cationic polymer has desirable biocompatibility, biodegradability, and antimicrobial capacity. Furthermore, chitosan displays potential to promote mineralization offering therapeutic potentials for both pulp and dentin tissues. However, its reduced solubility in neutral aqueous and organic solutions are current concerns and a focus of current chitosan scaffold research [114,116].

Synthetic scaffold designs provide an enhanced capacity to optimize mechanical strength and molecular delivery for a targeted therapeutic approach as shown in the Table 1 [21,143]. The table describes diverse biomedical approaches to achieve the endodontic regeneration [21,112]. Current biomaterials research pursues key functionalities for endodontic and periodontal tissue healing. For example, many novel scaffolds involve sustained delivery of therapeutic compounds including antimicrobials and signaling molecules (e.g., growth factors). Furthermore, synthetic scaffolds employ sites for enzymatic degradation to foster restoration of bio functional pulp-dentin tissue. Recently developed peptide amphiphile (PA)-based biomaterials are an example of a synthetic scaffold and offer potential promise in regenerative endodontics. The use of a PA hydrogel with stem cells from human exfoliated deciduous teeth (SHED) or DPSC in vitro demonstrated similar trends where both cell types were able to proliferate, differentiate, and yield mineralized deposits [134]. Studies implanting a self-assembled peptide scaffold containing dental stem cells reported dental pulp regeneration in one-third of the prepared dentin cylinders in rat teeth; however, full-length root pulp regeneration still needs more research $[131,144]$.

Table 1. Summary of recent biomedical approaches in regenerative endodontics (adapted from work in $[21,112])$.

\begin{tabular}{|c|c|c|c|}
\hline Stem Cells & Scaffold & Findings & Reference \\
\hline Pulp fibroblasts & PGA, collagen I, alginate & Pulp-like tissue after 45 to 60 days on PGA & {$[117,118]$} \\
\hline \multirow{9}{*}{ Human DPSCs } & $\begin{array}{l}\text { Col Type I with CP and } \\
\text { DMP-1 }\end{array}$ & New pulp-like tissue formation and organization & [119] \\
\hline & $\begin{array}{l}\text { Collagens I and III, chitosan, } \\
\text { gelatin }\end{array}$ & Adhesion and proliferation & [66] \\
\hline & NF-PCL/gelatin/nHA & $\begin{array}{l}\text { DPSC differentiation toward an odontoblast-like cells } \\
\text { in vitro and in vivo }\end{array}$ & [120] \\
\hline & NF-PLLA & $\begin{array}{l}\text { Attachment, proliferation, and differentiation of } \\
\text { human DPSCs }\end{array}$ & [121] \\
\hline & Self-assembling MDP & Pulp-like tissue formation & [111] \\
\hline & DDM-PLGA/Co-Cs-HA & $\begin{array}{l}\text { Potential as attractive scaffolds for odontogenic } \\
\text { differentiation }\end{array}$ & [122] \\
\hline & 3D Col/HA/PLCL & DPSC Differentiation and proliferation & [123] \\
\hline & $\begin{array}{l}\text { Self-assembling peptide } \\
\quad\left(\text { Puramatrix }{ }^{\mathrm{TM}} \text { ) }\right.\end{array}$ & DPSC survival, proliferation, and differentiation & [124] \\
\hline & Porous chitosan/Col & $\begin{array}{l}\text { Release of BMP-7 gene; DPSC differentiation into } \\
\text { odontoblast-like cells in vitro and in vivo }\end{array}$ & [125] \\
\hline
\end{tabular}


Table 1. Cont.

\begin{tabular}{|c|c|c|c|}
\hline Stem Cells & Scaffold & Findings & Reference \\
\hline \multirow{3}{*}{$\begin{array}{l}\text { Dog mobilized } \\
\text { DPSCs }\end{array}$} & \multirow{3}{*}{ Col with G-CSF } & Ectopic model, pulp-like tissue regeneration & [126] \\
\hline & & Complete pulp-like and dentin-like tissue regeneration & [127] \\
\hline & & $\begin{array}{l}\text { Orthotopic model; Less volume of regenerated } \\
\text { pulp-like tissue in aged dogs compared with that in } \\
\text { young dogs }\end{array}$ & [128] \\
\hline \multirow{3}{*}{ SHED } & PLLA & Pulp-like tissue formation & [129] \\
\hline & 3dimension dense Col & Odontogenic cell differentiation and mineralization & [130] \\
\hline & $\begin{array}{l}\text { Peptide(Puramatrix }{ }^{\mathrm{TM}} \text { ) with } \\
\text { rhCol type I }\end{array}$ & $\begin{array}{l}\text { SHED injected into full-length human root canals } \\
\text { differentiate into functional odontoblasts }\end{array}$ & [131] \\
\hline \multirow{2}{*}{ DPSCs \& SHED } & HA/ТCP & $\begin{array}{l}\text { Generation of dentin or bone (SHED) and } \\
\text { dentin-pulp-like complexes (DPSC) }\end{array}$ & {$[132,133]$} \\
\hline & PA self-assembling NF & $\begin{array}{l}\text { Easy to handle; introduced into small defects; cell } \\
\text { proliferation }\end{array}$ & [134] \\
\hline DPSCs \& SCAPs & Poly-D,L-lactide/glycolide & $\begin{array}{l}\text { Pulp-like tissue formation with vascularity and } \\
\text { dentin-like structure }\end{array}$ & [135] \\
\hline $\begin{array}{l}\text { DPSCs, SCAPs, } \\
\text { PDLSCs, and } \\
\text { BMSSCs }\end{array}$ & PEGylated fibrin gel & $\begin{array}{l}\text { All types of dental stem cells proliferated; excellent } \\
\text { biocompatibility; insertion into small defects }\end{array}$ & [136] \\
\hline \multirow{6}{*}{ No Stem Cells } & Alginate with TGF- $\beta 1$ & Release of TGF- $\beta 1$; odontoblast-like cell differentiation & [137] \\
\hline & $\begin{array}{l}\text { Gelatin incorporation of } \\
\text { FGF-2 }\end{array}$ & $\begin{array}{l}\text { Release of FGF-2; Induces the invasion of dental pulp } \\
\text { cells and vessels }\end{array}$ & [138] \\
\hline & $\begin{array}{l}\text { NF-PLGA/PLLA scaffolds } \\
\text { with DOXY }\end{array}$ & $\begin{array}{l}\text { Release of DOXY; inhibition of bacterial growth for a } \\
\text { prolonged duration }\end{array}$ & [139] \\
\hline & $\begin{array}{l}\text { GF-laden peptide with } \\
\text { VEGF, TGF } \beta-1 \text {, and FGF-2 }\end{array}$ & $\begin{array}{l}\text { Release of VEGF, TGF- } \beta 1 \text {, and FGF2; odontoblast-like } \\
\text { cell differentiation; pulp-like tissue formation }\end{array}$ & [140] \\
\hline & $\begin{array}{l}\text { NF PDS II-with MET and } \\
\text { CIP }\end{array}$ & $\begin{array}{l}\text { Release MET or CIP; antimicrobial activity against } E f \\
\text { and } P g\end{array}$ & [141] \\
\hline & NF PDS II-HNTs & $\begin{array}{l}\text { Potential in the development of a bioactive scaffold for } \\
\text { regenerative endodontics }\end{array}$ & [142] \\
\hline
\end{tabular}

PGA: poly glycolic acid; DPSCs: dental pulp stem cells; Col: collagen; CP: ceramic powder; DMP-1: dentin matrix protein 1; NF: nanofibrous; PCL: poly $\varepsilon$-caprolactone; nHA: nano-hydroxyapatite; PLLA: Poly L-lactic acid; MDP: multidomain peptides; DDM: demineralized dentin matrix; PLGA: poly lactic-co-glycolic acid; $\mathrm{Co}-\mathrm{CS}-\mathrm{HA}$ : collagen-chondroitin sulfate-hyaluronic acid; PLCL: poly L-lactide-co- $\varepsilon$-caprolactone; BMP-7: human bone morphogenetic protein-7; G-CSF: granulocyte colony-stimulating factor; SHEDs: stem cells from human exfoliated deciduous teeth; rhCol: recombinant human collagen; TCP: tricalcium phosphate; PA: peptide-amphiphile; SCAPs: stem cells from root apical papilla; PDLSCs: periodontal ligament stem cells; BMSSCs: bone marrow stromal stem cells; PEG: polyethylene glycol; TGF- $\beta 1$ : transforming growth factor $\beta$ family; FGF-2: fibroblast growth factor-2; DOXY: doxycycline; GF: growth factor; VEGF: vascular endothelial growth factor; PDS-II: nanocomposite scaffold composed of polydioxanone; MET: metronidazole; CIP: Ciprofloxacin; Ef: Enterococcus faecalis; Pg: Porphyromonas gingivalis; HNT: halloysite nanotubes. (The inserted table highlighted the current finding of recent biomedical approaches in regenerative endodontics that was adapted from the two references with the permitted citations and adaptation from the publisher (Sage Publication). I read that the policy about the table adaptation would not need mention the copyright permission).

Among the newly developed synthetic polymer, a NO releasing biomimetic nanomatrix gel was evaluated as a nature mimicking novel PA based scaffold [145]. This self-assembled PA gel mimics the ECM and provides a controlled release of NO, showing the therapeutic roles of disinfection, revascularization, and regeneration [146] (Figure 2). The antibacterial aspect of NO is critical for dental pulp regeneration to ensure a sterile pulp-dentin tissue environment and recruit healthy cell growth including DPSCs and neurovascular cells to promote revascularization. A study using the NO releasing PA gel found blood vessel formation as well as odontoblast-like cells in a beagle model; the findings draw attention to the potential of NO to promote stem cell homing and differentiation [145]. This ability to induce DPSC differentiation into dentin producing odontoblasts further highlights the potential of $\mathrm{NO}$ in dental pulp regeneration. 


\section{Summary}

Pulp-dentin tissue regeneration is the series of healing progression from an inflammatory response, immune signaling, and cellular interaction accompanying tissue restoration upon infectious exposure. Due to the unique anatomy of the tooth, infectious tissue damage extends toward the periapical and periodontal regions; therefore, cellular communication among the pluripotent pulp stem cells and immune cells is crucial for an appropriate response. Along with cellular signaling, migrating MSCs, such as DPSCs, could proliferate and differentiate into the pulp-dentin tissue-forming cells including neurovascular tissue regrowth as part of pulp-dentin tissue healing response. The tissue-healing phase is regulated by the anti-inflammatory M2 macrophage following the inflammatory phase. In fact, MSCs are associated with the further promotion of anti-inflammatory M2 macrophage polarization. Meanwhile, consequent tissue regeneration would occur with the facilitation of ECM mimicking bioactive scaffolds and mesenchymal cellular potential. Among the numerous biomedical approaches, recent development of the NO releasing biomimetic nanomatrix gel may provide the necessary supportive function for the pulp-dentin tissue microenvironment to regenerate optimal root dentin and pulp vitality. NO possesses a significant effect on inflammation and tissue healing with the antimicrobial, angiogenic, wound healing, and immunomodulatory properties.

Author Contributions: Conceptualization, H.-W.J. and K.C.; resources, J.V., J.C., H.-D.J., P.Z., H.W., H.-W.J., and K.C.; writing—original draft preparation, D.S., J.V., D.H., H.-D.J., J.-H.K., and K.C.; writing—review and editing, D.S., T.L., D.H., J.-H.K., H.-W.J., and K.C.; visualization, K.C.; supervision, K.C.; project administration, K.C.; funding acquisition, H.-W.J. and K.C. All authors have read and agreed to the published version of the manuscript.

Funding: This research was supported by the following grants: (1) National Institutes of Health/National Institute of Dental and Craniofacial Research, K08 (KDE027401A); (2) AADR Anne Haffajee Fellowship; (3) National Institutes of Health, R01 (1R01HL125391).

Conflicts of Interest: The authors declare no conflicts of interest.

\section{References}

1. Robertson, D.P.; Keys, W.; Rautemaa-Richardson, R.; Burns, R.; Smith, A.J. Management of severe acute dental infections. BMJ 2015, 350, h1300. [CrossRef]

2. Sanders, J.L.; Houck, R.C. Dental Abscess. In StatPearls; StatPearls Publishing LLC: Las Vegas, NV, USA, 2019; Volume 2019.

3. Dye, B.A.; Li, X.; Thorton-Evans, G. Oral Health Disparities as Determined by Selected Healthy People 2020 Oral Health Objectives for the United States, 2009-2010; NCHS Data Briefs; Centers for Disease Control and Prevention: Atlanta, GA, USA, 2012; pp. 1-8.

4. Hargreaves, K.M.; Diogenes, A.; Teixeira, F.B. Treatment options: Biological basis of regenerative endodontic procedures. J. Endod. 2013, 39, S30-S43. [CrossRef] [PubMed]

5. Ostby, B.N. The role of the blood clot in endodontic therapy. An experimental histologic study. Acta Odontol. Scand. 1961, 19, 324-353. [CrossRef] [PubMed]

6. AAE. Regenerative Endodontics. In Endodontics Colleagues for Excellence; American Association of Endodontists: Chicago, IL, USA, 2013; pp. 1-8.

7. Murray, P.E.; Garcia-Godoy, F.; Hargreaves, K.M. Regenerative endodontics: A review of current status and a call for action. J. Endod. 2007, 33, 377-390. [CrossRef] [PubMed]

8. Paranjpe, A.K. Are Regenerative Endodontic Procedures Working? Available online: https://www.aae.org/ specialty/2019/09/30/are-regenerative-endodontic-procedures-working/\# (accessed on 3 October 2019).

9. Reynolds, K.; Johnson, J.D.; Cohenca, N. Pulp revascularization of necrotic bilateral bicuspids using a modified novel technique to eliminate potential coronal discolouration: A case report. Int. Endod. J. 2009, 42, 84-92. [CrossRef] [PubMed]

10. Kim, S.T.; Abbott, P.V.; McGinley, P. The effects of Ledermix paste on discolouration of immature teeth. Int. Endod. J. 2000, 33, 233-237. [CrossRef] [PubMed]

11. Dabbagh, B.; Alvaro, E.; Vu, D.D.; Rizkallah, J.; Schwartz, S. Clinical complications in the revascularization of immature necrotic permanent teeth. Pediatr. Dent. 2012, 34, 414-417. 
12. Andreasen, J.O.; Farik, B.; Munksgaard, E.C. Long-term calcium hydroxide as a root canal dressing may increase risk of root fracture. Dent. Traumatol. 2002, 18, 134-137. [CrossRef]

13. Rosenberg, B.; Murray, P.E.; Namerow, K. The effect of calcium hydroxide root filling on dentin fracture strength. Dent. Traumatol. 2007, 23, 26-29. [CrossRef]

14. Yassen, G.H.; Chu, T.M.; Eckert, G.; Platt, J.A. Effect of medicaments used in endodontic regeneration technique on the chemical structure of human immature radicular dentin: An in vitro study. J. Endod. 2013, 39, 269-273. [CrossRef]

15. Cvek, M. Prognosis of luxated non-vital maxillary incisors treated with calcium hydroxide and filled with gutta-percha. A retrospective clinical study. Endod. Dent. Traumatol. 1992, 8, 45-55. [CrossRef]

16. Wang, X.; Thibodeau, B.; Trope, M.; Lin, L.M.; Huang, G.T. Histologic characterization of regenerated tissues in canal space after the revitalization/revascularization procedure of immature dog teeth with apical periodontitis. J. Endod. 2010, 36, 56-63. [CrossRef]

17. Shimizu, E.; Jong, G.; Partridge, N.; Rosenberg, P.A.; Lin, L.M. Histologic observation of a human immature permanent tooth with irreversible pulpitis after revascularization/regeneration procedure. J. Endod. 2012, 38, 1293-1297. [CrossRef]

18. Nosrat, A.; Homayounfar, N.; Oloomi, K. Drawbacks and unfavorable outcomes of regenerative endodontic treatments of necrotic immature teeth: A literature review and report of a case. J. Endod. 2012, 38, 1428-1434. [CrossRef]

19. Chen, M.Y.; Chen, K.L.; Chen, C.A.; Tayebaty, F.; Rosenberg, P.A.; Lin, L.M. Responses of immature permanent teeth with infected necrotic pulp tissue and apical periodontitis/abscess to revascularization procedures. Int. Endod. J. 2012, 45, 294-305. [CrossRef] [PubMed]

20. Huang, G.T. Dental pulp and dentin tissue engineering and regeneration: Advancement and challenge. Front. Biosci. Elite Ed. 2011, 3, 788-800. [CrossRef] [PubMed]

21. Albuquerque, M.T.; Valera, M.C.; Nakashima, M.; Nor, J.E.; Bottino, M.C. Tissue-engineering-based strategies for regenerative endodontics. J. Dent. Res. 2014, 93, 1222-1231. [CrossRef]

22. Rombouts, C.; Giraud, T.; Jeanneau, C.; About, I. Pulp Vascularization during Tooth Development, Regeneration, and Therapy. J. Dent. Res. 2017, 96, 137-144. [CrossRef] [PubMed]

23. Schmalz, G.; Smith, A.J. Pulp development, repair, and regeneration: Challenges of the transition from traditional dentistry to biologically based therapies. J. Endod. 2014, 40, S2-S5. [CrossRef] [PubMed]

24. Mao, J.J.; Kim, S.G.; Zhou, J.; Ye, L.; Cho, S.; Suzuki, T.; Fu, S.Y.; Yang, R.; Zhou, X. Regenerative endodontics: Barriers and strategies for clinical translation. Dent. Clin. 2012, 56, 639-649. [CrossRef]

25. Huang, G.T.; Gronthos, S.; Shi, S. Mesenchymal stem cells derived from dental tissues vs. those from other sources: Their biology and role in regenerative medicine. J. Dent. Res. 2009, 88, 792-806. [CrossRef] [PubMed]

26. Langer, R.; Vacanti, J.P. Tissue engineering. Science 1993, 260, 920-926. [CrossRef] [PubMed]

27. Galler, K.M.; D'Souza, R.N. Tissue engineering approaches for regenerative dentistry. Regen. Med. 2011, 6, 111-124. [CrossRef] [PubMed]

28. Yildirim, S.; Can, A.; Arican, M.; Embree, M.C.; Mao, J.J. Characterization of dental pulp defect and repair in a canine model. Am. J. Dent. 2011, 24, 331-335. [PubMed]

29. Veerayutthwilai, O.; Byers, M.R.; Pham, T.T.; Darveau, R.P.; Dale, B.A. Differential regulation of immune responses by odontoblasts. Oral. Microbiol. Immunol. 2007, 22, 5-13. [CrossRef] [PubMed]

30. Farges, J.C.; Alliot-Licht, B.; Renard, E.; Ducret, M.; Gaudin, A.; Smith, A.J.; Cooper, P.R. Dental Pulp Defence and Repair Mechanisms in Dental Caries. Mediat. Inflamm. 2015, 2015, 230251. [CrossRef]

31. Jontell, M.; Gunraj, M.N.; Bergenholtz, G. Immunocompetent cells in the normal dental pulp. J. Dent. Res. 1987, 66, 1149-1153. [CrossRef]

32. Goldberg, M.; Farges, J.C.; Lacerda-Pinheiro, S.; Six, N.; Jegat, N.; Decup, F.; Septier, D.; Carrouel, F.; Durand, S.; Chaussain-Miller, C.; et al. Inflammatory and immunological aspects of dental pulp repair. Pharmacol. Res. 2008, 58, 137-147. [CrossRef]

33. Eming, S.A.; Krieg, T.; Davidson, J.M. Inflammation in wound repair: Molecular and cellular mechanisms. J. Investig. Dermatol. 2007, 127, 514-525. [CrossRef]

34. Ten Cate, A.R. The role of epithelium in the development, structure and function of the tissues of tooth support. Oral Dis. 1996, 2, 55-62. [CrossRef] 
35. Ricucci, D.; Siqueira, J.F.; Loghin, S.; Lin, L.M. Pulp and apical tissue response to deep caries in immature teeth: A histologic and histobacteriologic study. J. Dent. 2017, 56, 19-32. [CrossRef] [PubMed]

36. Huang, G.T.; Sonoyama, W.; Liu, Y.; Liu, H.; Wang, S.; Shi, S. The hidden treasure in apical papilla: The potential role in pulp/dentin regeneration and bioroot engineering. J. Endod. 2008, 34, 645-651. [CrossRef] [PubMed]

37. Joo, K.H.; Song, J.S.; Kim, S.; Lee, H.S.; Jeon, M.; Kim, S.O.; Lee, J.H. Cytokine Expression of Stem Cells Originating from the Apical Complex and Coronal Pulp of Immature Teeth. J. Endod. 2018, 44, 87-92. [CrossRef]

38. Xu, L.; Tang, L.; Jin, F.; Liu, X.H.; Yu, J.H.; Wu, J.J.; Yang, Z.H.; Wang, Y.X.; Duan, Y.Z.; Jin, Y. The apical region of developing tooth root constitutes a complex and maintains the ability to generate root and periodontium-like tissues. J. Periodontal Res. 2009, 44, 275-282. [CrossRef]

39. El-Meligy, O.A.; Avery, D.R. Comparison of mineral trioxide aggregate and calcium hydroxide as pulpotomy agents in young permanent teeth (apexogenesis). Pediatr. Dent. 2006, 28, 399-404. [PubMed]

40. Gupta, S.S.; Shetty, D.C.; Urs, A.B.; Nainani, P. Role of inflammation in developmental odontogenic pathosis. J. Oral Maxillofac. Pathol. 2016, 20, 164. [CrossRef]

41. Chen, S.Y.; Wang, H.L.; Glickman, G.N. The influence of endodontic treatment upon periodontal wound healing. J. Clin. Periodontol. 1997, 24, 449-456. [CrossRef]

42. Jenkins, G.W.; Bresnen, D.; Jenkins, E.; Mullen, N. Dental Abscess in Pediatric Patients: A Marker of Neglect. Pediatr. Emerg. Care 2018, 34, 774-777. [CrossRef]

43. Thibodeau, B.; Trope, M. Pulp revascularization of a necrotic infected immature permanent tooth: Case report and review of the literature. Pediatr. Dent. 2007, 29, 47-50.

44. Jeeruphan, T.; Jantarat, J.; Yanpiset, K.; Suwannapan, L.; Khewsawai, P.; Hargreaves, K.M. Mahidol study 1: Comparison of radiographic and survival outcomes of immature teeth treated with either regenerative endodontic or apexification methods: A retrospective study. J. Endod. 2012, 38, 1330-1336. [CrossRef]

45. Garcia-Godoy, F.; Murray, P.E. Recommendations for using regenerative endodontic procedures in permanent immature traumatized teeth. Dent. Traumatol. 2012, 28, 33-41. [CrossRef] [PubMed]

46. Di Nardo Di Maio, F.; Lohinai, Z.; D’Arcangelo, C.; De Fazio, P.E.; Speranza, L.; De Lutiis, M.A.; Patruno, A.; Grilli, A.; Felaco, M. Nitric oxide synthase in healthy and inflamed human dental pulp. J. Dent. Res. 2004, 83, 312-316. [CrossRef] [PubMed]

47. Moncada, S.; Higgs, A. The L-arginine-nitric oxide pathway. N. Engl. J. Med. 1993, 329, 2002-2012. [CrossRef] [PubMed]

48. Durand, S.H.; Flacher, V.; Roméas, A.; Carrouel, F.; Colomb, E.; Vincent, C.; Magloire, H.; Couble, M.L.; Bleicher, F.; Staquet, M.J.; et al. Lipoteichoic acid increases TLR and functional chemokine expression while reducing dentin formation in in vitro differentiated human odontoblasts. J. Immunol. 2006, 176, 2880-2887. [CrossRef] [PubMed]

49. Abbas, A.K. The control of T cell activation vs. tolerance. Autoimmun. Rev. 2003, 2, 115-118. [CrossRef]

50. Randolph, G.J.; Inaba, K.; Robbiani, D.F.; Steinman, R.M.; Muller, W.A. Differentiation of phagocytic monocytes into lymph node dendritic cells in vivo. Immunity 1999, 11, 753-761. [CrossRef]

51. Romagnani, S. Th1/Th2 cells. Inflamm. Bowel. Dis. 1999, 5, 285-294. [CrossRef]

52. Koh, T.J.; DiPietro, L.A. Inflammation and wound healing: The role of the macrophage. Expert Rev. Mol. Med. 2011, 13, e23. [CrossRef]

53. Kawashima, N.; Wongyaofa, I.; Suzuki, N.; Kawanishi, H.N.; Suda, H. NK and NKT cells in the rat dental pulp tissues. Oral Surg. Oral Med. Oral Pathol. Oral Radiol. Endod. 2006, 102, 558-563. [CrossRef]

54. Bayry, J.; Lacroix-Desmazes, S.; Kazatchkine, M.D.; Hermine, O.; Tough, D.F.; Kaveri, S.V. Modulation of dendritic cell maturation and function by B lymphocytes. J. Immunol. 2005, 175, 15-20. [CrossRef]

55. Kubes, P.; Suzuki, M.; Granger, D.N. Nitric oxide: An endogenous modulator of leukocyte adhesion. Proc. Natl. Acad. Sci. USA 1991, 88, 4651-4655. [CrossRef] [PubMed]

56. Goldberg, M.; Njeh, A.; Uzunoglu, E. Is Pulp Inflammation a Prerequisite for Pulp Healing and Regeneration? Mediat. Inflamm. 2015, 2015, 347649. [CrossRef]

57. Murdoch, C. CXCR4: Chemokine receptor extraordinaire. Immunol. Rev. 2000, 177, 175-184. [CrossRef] [PubMed] 
58. He, W.; Wang, Z.; Luo, Z.; Yu, Q.; Jiang, Y.; Zhang, Y.; Zhou, Z.; Smith, A.J.; Cooper, P.R. LPS promote the odontoblastic differentiation of human dental pulp stem cells via MAPK signaling pathway. J. Cell. Physiol. 2015, 230, 554-561. [CrossRef] [PubMed]

59. Miller, R.J.; Banisadr, G.; Bhattacharyya, B.J. CXCR4 signaling in the regulation of stem cell migration and development. J. Neuroimmunol. 2008, 198, 31-38. [CrossRef] [PubMed]

60. Li, Z.; Jiang, C.M.; An, S.; Cheng, Q.; Huang, Y.F.; Wang, Y.T.; Gou, Y.C.; Xiao, L.; Yu, W.J.; Wang, J. Immunomodulatory properties of dental tissue-derived mesenchymal stem cells. Oral Dis. 2014, 20, 25-34. [CrossRef]

61. Velnar, T.; Bailey, T.; Smrkolj, V. The wound healing process: An overview of the cellular and molecular mechanisms. J. Int. Med. Res. 2009, 37, 1528-1542. [CrossRef]

62. Nakashima, M.; Akamine, A. The application of tissue engineering to regeneration of pulp and dentin in endodontics. J. Endod. 2005, 31, 711-718. [CrossRef]

63. Nuti, N.; Corallo, C.; Chan, B.M.; Ferrari, M.; Gerami-Naini, B. Multipotent Differentiation of Human Dental Pulp Stem Cells: A Literature Review. Stem Cell. Rev. 2016. [CrossRef]

64. Lu, Q.; Pandya, M.; Rufaihah, A.J.; Rosa, V.; Tong, H.J.; Seliktar, D.; Toh, W.S. Modulation of Dental Pulp Stem Cell Odontogenesis in a Tunable PEG-Fibrinogen Hydrogel System. Stem Cells Int. 2015, 2015, 525367. [CrossRef]

65. Teti, G.; Salvatore, V.; Focaroli, S.; Durante, S.; Mazzotti, A.; Dicarlo, M.; Mattioli-Belmonte, M.; Orsini, G. In vitro osteogenic and odontogenic differentiation of human dental pulp stem cells seeded on carboxymethyl cellulose-hydroxyapatite hybrid hydrogel. Front. Physiol. 2015, 6, 297. [CrossRef] [PubMed]

66. Kim, N.R.; Lee, D.H.; Chung, P.H.; Yang, H.C. Distinct differentiation properties of human dental pulp cells on collagen, gelatin, and chitosan scaffolds. Oral Surg. Oral Med. Oral Pathol. Oral Radiol. Endod. 2009, 108, e94-e100. [CrossRef] [PubMed]

67. Arthur, A.; Rychkov, G.; Shi, S.; Koblar, S.A.; Gronthos, S. Adult human dental pulp stem cells differentiate toward functionally active neurons under appropriate environmental cues. Stem Cells 2008, 26, 1787-1795. [CrossRef] [PubMed]

68. D’Aquino, R.; Graziano, A.; Sampaolesi, M.; Laino, G.; Pirozzi, G.; De Rosa, A.; Papaccio, G. Human postnatal dental pulp cells co-differentiate into osteoblasts and endotheliocytes: A pivotal synergy leading to adult bone tissue formation. Cell Death Differ. 2007, 14, 1162-1171. [CrossRef]

69. Roberts-Clark, D.J.; Smith, A.J. Angiogenic growth factors in human dentine matrix. Arch. Oral Biol. 2000, 45, 1013-1016. [CrossRef]

70. Mathieu, S.; El-Battari, A.; Dejou, J.; About, I. Role of injured endothelial cells in the recruitment of human pulp cells. Arch. Oral Biol. 2005, 50, 109-113. [CrossRef]

71. Ullah, I.; Subbarao, R.B.; Rho, G.J. Human mesenchymal stem cells-Current trends and future prospective. Biosci. Rep. 2015, 35. [CrossRef]

72. Evans, M.J.; Kaufman, M.H. Establishment in culture of pluripotential cells from mouse embryos. Nature 1981, 292, 154-156. [CrossRef]

73. Takahashi, K.; Yamanaka, S. Induction of pluripotent stem cells from mouse embryonic and adult fibroblast cultures by defined factors. Cell 2006, 126, 663-676. [CrossRef]

74. Pittenger, M.F.; Mackay, A.M.; Beck, S.C.; Jaiswal, R.K.; Douglas, R.; Mosca, J.D.; Moorman, M.A.; Simonetti, D.W.; Craig, S.; Marshak, D.R. Multilineage potential of adult human mesenchymal stem cells. Science 1999, 284, 143-147. [CrossRef]

75. Bartsch, G.; Yoo, J.J.; De Coppi, P.; Siddiqui, M.M.; Schuch, G.; Pohl, H.G.; Fuhr, J.; Perin, L.; Soker, S.; Atala, A. Propagation, expansion, and multilineage differentiation of human somatic stem cells from dermal progenitors. Stem Cells Dev. 2005, 14, 337-348. [CrossRef] [PubMed]

76. Yianni, V.; Sharpe, P.T. Perivascular-Derived Mesenchymal Stem Cells. J. Dent. Res. 2019. [CrossRef] [PubMed]

77. Tomar, G.B.; Srivastava, R.K.; Gupta, N.; Barhanpurkar, A.P.; Pote, S.T.; Jhaveri, H.M.; Mishra, G.C.; Wani, M.R. Human gingiva-derived mesenchymal stem cells are superior to bone marrow-derived mesenchymal stem cells for cell therapy in regenerative medicine. Biochem. Biophys. Res. Commun. 2010, 393, 377-383. [CrossRef] [PubMed]

78. Sharpe, P.T. Dental mesenchymal stem cells. Development 2016, 143, 2273-2280. [CrossRef] [PubMed] 
79. Feng, J.; Mantesso, A.; De Bari, C.; Nishiyama, A.; Sharpe, P.T. Dual origin of mesenchymal stem cells contributing to organ growth and repair. Proc. Natl. Acad. Sci. USA 2011, 108, 6503-6508. [CrossRef]

80. Whyte, J.L.; Smith, A.A.; Helms, J.A. Wnt signaling and injury repair. Cold Spring Harb Perspect. Biol. 2012, 4, a008078. [CrossRef]

81. Yamaza, T.; Kentaro, A.; Chen, C.; Liu, Y.; Shi, Y.; Gronthos, S.; Wang, S.; Shi, S. Immunomodulatory properties of stem cells from human exfoliated deciduous teeth. Stem Cell Res. Ther. 2010, 1, 5. [CrossRef]

82. Zhang, Q.Z.; Su, W.R.; Shi, S.H.; Wilder-Smith, P.; Xiang, A.P.; Wong, A.; Nguyen, A.L.; Kwon, C.W.; Le, A.D. Human gingiva-derived mesenchymal stem cells elicit polarization of $\mathrm{m} 2$ macrophages and enhance cutaneous wound healing. Stem Cells 2010, 28, 1856-1868. [CrossRef]

83. Caplan, A.I.; Correa, D. The MSC: An injury drugstore. Cell Stem Cell 2011, 9, 11-15. [CrossRef]

84. Lin, L.; Chen, M.Y.; Ricucci, D.; Rosenberg, P.A. Guided tissue regeneration in periapical surgery. J. Endod. 2010, 36, 618-625. [CrossRef]

85. Page, R.C. The role of inflammatory mediators in the pathogenesis of periodontal disease. J. Periodontal Res. 1991, 26, 230-242. [CrossRef] [PubMed]

86. Stashenko, P.; Teles, R.; D'Souza, R. Periapical inflammatory responses and their modulation. Crit. Rev. Oral Biol. Med. 1998, 9, 498-521. [CrossRef] [PubMed]

87. Kinaia, B.M.; Chogle, S.M.; Kinaia, A.M.; Goodis, H.E. Regenerative therapy: A periodontal-endodontic perspective. Dent. Clin. 2012, 56, 537-547. [CrossRef]

88. Bashutski, J.D.; Wang, H.L. Periodontal and endodontic regeneration. J. Endod. 2009, 35, 321-328. [CrossRef] [PubMed]

89. Sanchez-Torres, A.; Sanchez-Garces, M.A.; Gay-Escoda, C. Materials and prognostic factors of bone regeneration in periapical surgery: A systematic review. Med. Oral Patol. Oral Cir. Bucal. 2014, 19, e419-e425. [CrossRef]

90. Anderson, J.M.; Rodriguez, A.; Chang, D.T. Foreign body reaction to biomaterials. Semin. Immunol. 2008, 20, 86-100. [CrossRef]

91. Morand, D.N.; Davideau, J.L.; Clauss, F.; Jessel, N.; Tenenbaum, H.; Huck, O. Cytokines during periodontal wound healing: Potential application for new therapeutic approach. Oral Dis. 2017, 23, 300-311. [CrossRef]

92. Witte, M.B.; Barbul, A. Role of nitric oxide in wound repair. Am. J. Surg. 2002, 183, 406-412. [CrossRef]

93. Carpenter, A.W.; Schoenfisch, M.H. Nitric oxide release: Part II. Therapeutic applications. Chem. Soc. Rev. 2012, 41, 3742-3752. [CrossRef]

94. Fukumura, D.; Kashiwagi, S.; Jain, R.K. The role of nitric oxide in tumour progression. Nat. Rev. Cancer 2006, 6, 521-534. [CrossRef]

95. Klein-Nulend, J.; van Oers, R.F.; Bakker, A.D.; Bacabac, R.G. Nitric oxide signaling in mechanical adaptation of bone. Osteoporos. Int. 2014, 25, 1427-1437. [CrossRef] [PubMed]

96. Rong, F.; Tang, Y.; Wang, T.; Feng, T.; Song, J.; Li, P.; Huang, W. Nitric Oxide-Releasing Polymeric Materials for Antimicrobial Applications: A Review. Antioxidants 2019, 8, 556. [CrossRef] [PubMed]

97. Choudhari, S.K.; Chaudhary, M.; Bagde, S.; Gadbail, A.R.; Joshi, V. Nitric oxide and cancer: A review. World J. Surg. Oncol. 2013, 11, 118. [CrossRef] [PubMed]

98. Armour, K.E.; Armour, K.J.; Gallagher, M.E.; Godecke, A.; Helfrich, M.H.; Reid, D.M.; Ralston, S.H. Defective bone formation and anabolic response to exogenous estrogen in mice with targeted disruption of endothelial nitric oxide synthase. Endocrinology 2001, 142, 760-766. [CrossRef] [PubMed]

99. Sonoda, S.; Mei, Y.F.; Atsuta, I.; Danjo, A.; Yamaza, H.; Hama, S.; Nishida, K.; Tang, R.; Kyumoto-Nakamura, Y.; Uehara, N.; et al. Exogenous nitric oxide stimulates the odontogenic differentiation of rat dental pulp stem cells. Sci. Rep. 2018, 8, 3419. [CrossRef] [PubMed]

100. Uehara, E.U.; Shida Bde, S.; de Brito, C.A. Role of nitric oxide in immune responses against viruses: Beyond microbicidal activity. Inflamm. Res. 2015, 64, 845-852. [CrossRef]

101. Lu, G.; Zhang, R.; Geng, S.; Peng, L.; Jayaraman, P.; Chen, C.; Xu, F.; Yang, J.; Li, Q.; Zheng, H.; et al. Myeloid cell-derived inducible nitric oxide synthase suppresses M1 macrophage polarization. Nat. Commun. 2015, 6, 6676. [CrossRef]

102. Lee, W.J.; Tateya, S.; Cheng, A.M.; Rizzo-DeLeon, N.; Wang, N.F.; Handa, P.; Wilson, C.L.; Clowes, A.W.; Sweet, I.R.; Bomsztyk, K.; et al. M2 Macrophage Polarization Mediates Anti-inflammatory Effects of Endothelial Nitric Oxide Signaling. Diabetes 2015, 64, 2836-2846. [CrossRef] 
103. Mancini, L.; Moradi-Bidhendi, N.; Becherini, L.; Martineti, V.; MacIntyre, I. The biphasic effects of nitric oxide in primary rat osteoblasts are cGMP dependent. Biochem. Biophys. Res. Commun. 2000, 274, 477-481. [CrossRef]

104. Riancho, J.A.; Salas, E.; Zarrabeitia, M.T.; Olmos, J.M.; Amado, J.A.; Fernandez-Luna, J.L.; Gonzalez-Macias, J. Expression and functional role of nitric oxide synthase in osteoblast-like cells. J. Bone Miner. Res. 1995, 10, 439-446. [CrossRef]

105. Kalyanaraman, H.; Schall, N.; Pilz, R.B. Nitric oxide and cyclic GMP functions in bone. Nitric Oxide 2018, 76, 62-70. [CrossRef] [PubMed]

106. Meesters, D.M.; Neubert, S.; Wijnands, K.A.P.; Heyer, F.L.; Zeiter, S.; Ito, K.; Brink, P.R.G.; Poeze, M. Deficiency of inducible and endothelial nitric oxide synthase results in diminished bone formation and delayed union and nonunion development. Bone 2016, 83, 111-118. [CrossRef] [PubMed]

107. Colombo, J.S.; Moore, A.N.; Hartgerink, J.D.; D'Souza, R.N. Scaffolds to control inflammation and facilitate dental pulp regeneration. J. Endod. 2014, 40, S6-S12. [CrossRef] [PubMed]

108. Bottino, M.C.; Pankajakshan, D.; Nor, J.E. Advanced Scaffolds for Dental Pulp and Periodontal Regeneration. Dent. Clin. 2017, 61, 689-711. [CrossRef] [PubMed]

109. Gupte, M.J.; Ma, P.X. Nanofibrous scaffolds for dental and craniofacial applications. J. Dent. Res. 2012, 91, 227-234. [CrossRef] [PubMed]

110. Schmalz, G.; Galler, K.M. Biocompatibility of biomaterials-Lessons learned and considerations for the design of novel materials. Dent. Mater. Off. Publ. Acad. Dent. Mater. 2017, 33, 382-393. [CrossRef]

111. Galler, K.M.; Hartgerink, J.D.; Cavender, A.C.; Schmalz, G.; D'Souza, R.N. A customized self-assembling peptide hydrogel for dental pulp tissue engineering. Tissue Eng. Part A 2012, 18, 176-184. [CrossRef]

112. Galler, K.M.; D'Souza, R.N.; Hartgerink, J.D.; Schmalz, G. Scaffolds for dental pulp tissue engineering. Adv. Dent. Res. 2011, 23, 333-339. [CrossRef]

113. Galler, K.M.; Brandl, F.P.; Kirchhof, S.; Widbiller, M.; Eidt, A.; Buchalla, W.; Göpferich, A.; Schmalz, G. Suitability of Different Natural and Synthetic Biomaterials for Dental Pulp Tissue Engineering. Tissue Eng. Part A 2018, 24, 234-244. [CrossRef] [PubMed]

114. Chang, B.; Ahuja, N.; Ma, C.; Liu, X. Injectable scaffolds: Preparation and application in dental and craniofacial regeneration. Mater. Sci. Eng. R Rep. A Rev. J. 2017, 111, 1-26. [CrossRef] [PubMed]

115. Zein, N.; Harmouch, E.; Lutz, J.-C.; Fernandez De Grado, G.; Kuchler-Bopp, S.; Clauss, F.; Offner, D.; Hua, G.; Benkirane-Jessel, N.; Fioretti, F. Polymer-Based Instructive Scaffolds for Endodontic Regeneration. Materials 2019, 12, 2347. [CrossRef] [PubMed]

116. Aguilar, A.; Zein, N.; Harmouch, E.; Hafdi, B.; Bornert, F.; Offner, D.; Clauss, F.; Fioretti, F.; Huck, O.; Benkirane-Jessel, N.; et al. Application of Chitosan in Bone and Dental Engineering. Molecules 2019, 24, 3009. [CrossRef] [PubMed]

117. Mooney, D.J.; Powell, C.; Piana, J.; Rutherford, B. Engineering dental pulp-like tissue in vitro. Biotechnol. Prog. 1996, 12, 865-868. [CrossRef] [PubMed]

118. Bohl, K.S.; Shon, J.; Rutherford, B.; Mooney, D.J. Role of synthetic extracellular matrix in development of engineered dental pulp. J. Biomater. Sci. Polym. Ed. 1998, 9, 749-764. [CrossRef]

119. Prescott, R.S.; Alsanea, R.; Fayad, M.I.; Johnson, B.R.; Wenckus, C.S.; Hao, J.; John, A.S.; George, A. In vivo generation of dental pulp-like tissue by using dental pulp stem cells, a collagen scaffold, and dentin matrix protein 1 after subcutaneous transplantation in mice. J. Endod. 2008, 34, 421-426. [CrossRef]

120. Yang, X.; Yang, F.; Walboomers, X.F.; Bian, Z.; Fan, M.; Jansen, J.A. The performance of dental pulp stem cells on nanofibrous PCL/gelatin/nHA scaffolds. J. Biomed. Mater. Res. Part A 2010, 93, 247-257. [CrossRef] [PubMed]

121. Wang, J.; Ma, H.; Jin, X.; Hu, J.; Liu, X.; Ni, L.; Ma, P.X. The effect of scaffold architecture on odontogenic differentiation of human dental pulp stem cells. Biomaterials 2011, 32, 7822-7830. [CrossRef]

122. Zhang, H.; Liu, S.; Zhou, Y.; Tan, J.; Che, H.; Ning, F.; Zhang, X.; Xun, W.; Huo, N.; Tang, L.; et al. Natural mineralized scaffolds promote the dentinogenic potential of dental pulp stem cells via the mitogen-activated protein kinase signaling pathway. Tissue Eng. Part A 2012, 18, 677-691. [CrossRef]

123. Akkouch, A.; Zhang, Z.; Rouabhia, M. Engineering bone tissue using human dental pulp stem cells and an osteogenic collagen-hydroxyapatite-poly (L-lactide-co- $\varepsilon$-caprolactone) scaffold. J. Biomater. Appl. 2014, 28, 922-936. [CrossRef] 
124. Cavalcanti, B.N.; Zeitlin, B.D.; Nör, J.E. A hydrogel scaffold that maintains viability and supports differentiation of dental pulp stem cells. Dent. Mater. Off. Publ. Acad. Dent. Mater. 2013, 29, 97-102. [CrossRef]

125. Yang, X.; Han, G.; Pang, X.; Fan, M. Chitosan/collagen scaffold containing bone morphogenetic protein-7 DNA supports dental pulp stem cell differentiation in vitro and in vivo. J. Biomed. Mater. Res. Part A 2012. [CrossRef] [PubMed]

126. Murakami, M.; Horibe, H.; Iohara, K.; Hayashi, Y.; Osako, Y.; Takei, Y.; Nakata, K.; Motoyama, N.; Kurita, K.; Nakashima, M. The use of granulocyte-colony stimulating factor induced mobilization for isolation of dental pulp stem cells with high regenerative potential. Biomaterials 2013, 34, 9036-9047. [CrossRef] [PubMed]

127. Iohara, K.; Murakami, M.; Takeuchi, N.; Osako, Y.; Ito, M.; Ishizaka, R.; Utunomiya, S.; Nakamura, H.; Matsushita, K.; Nakashima, M. A novel combinatorial therapy with pulp stem cells and granulocyte colony-stimulating factor for total pulp regeneration. Stem cells Transl. Med. 2013, 2, 521-533. [CrossRef] [PubMed]

128. Iohara, K.; Murakami, M.; Nakata, K.; Nakashima, M. Age-dependent decline in dental pulp regeneration after pulpectomy in dogs. Exp. Gerontol. 2014, 52, 39-45. [CrossRef] [PubMed]

129. Cordeiro, M.M.; Dong, Z.; Kaneko, T.; Zhang, Z.; Miyazawa, M.; Shi, S.; Smith, A.J.; Nor, J.E. Dental pulp tissue engineering with stem cells from exfoliated deciduous teeth. J. Endod. 2008, 34, 962-969. [CrossRef] [PubMed]

130. Coyac, B.R.; Chicatun, F.; Hoac, B.; Nelea, V.; Chaussain, C.; Nazhat, S.N.; McKee, M.D. Mineralization of dense collagen hydrogel scaffolds by human pulp cells. J. Dent. Res. 2013, 92, 648-654. [CrossRef]

131. Rosa, V.; Zhang, Z.; Grande, R.H.; Nor, J.E. Dental pulp tissue engineering in full-length human root canals. J. Dent. Res. 2013, 92, 970-975. [CrossRef]

132. Gronthos, S.; Mankani, M.; Brahim, J.; Robey, P.G.; Shi, S. Postnatal human dental pulp stem cells (DPSCs) in vitro and in vivo. Proc. Natl. Acad. Sci. USA 2000, 97, 13625-13630. [CrossRef]

133. Miura, M.; Gronthos, S.; Zhao, M.; Lu, B.; Fisher, L.W.; Robey, P.G.; Shi, S. SHED: Stem cells from human exfoliated deciduous teeth. Proc. Natl. Acad. Sci. USA 2003, 100, 5807-5812. [CrossRef]

134. Galler, K.M.; Cavender, A.; Yuwono, V.; Dong, H.; Shi, S.; Schmalz, G.; Hartgerink, J.D.; D'Souza, R.N. Self-assembling peptide amphiphile nanofibers as a scaffold for dental stem cells. Tissue Eng. Part A 2008, 14, 2051-2058. [CrossRef]

135. Huang, G.T.; Yamaza, T.; Shea, L.D.; Djouad, F.; Kuhn, N.Z.; Tuan, R.S.; Shi, S. Stem/progenitor cell-mediated de novo regeneration of dental pulp with newly deposited continuous layer of dentin in an in vivo model. Tissue Eng. Part A 2010, 16, 605-615. [CrossRef] [PubMed]

136. Galler, K.M.; Cavender, A.C.; Koeklue, U.; Suggs, L.J.; Schmalz, G.; D’Souza, R.N. Bioengineering of dental stem cells in a PEGylated fibrin gel. Regen. Med. 2011, 6, 191-200. [CrossRef]

137. Dobie, K.; Smith, G.; Sloan, A.J.; Smith, A.J. Effects of alginate hydrogels and TGF-beta 1 on human dental pulp repair in vitro. Connect. Tissue Res. 2002, 43, 387-390. [CrossRef] [PubMed]

138. Ishimatsu, H.; Kitamura, C.; Morotomi, T.; Tabata, Y.; Nishihara, T.; Chen, K.-K.; Terashita, M. Formation of dentinal bridge on surface of regenerated dental pulp in dentin defects by controlled release of fibroblast growth factor-2 from gelatin hydrogels. J. Endod. 2009, 35, 858-865. [CrossRef] [PubMed]

139. Feng, K.; Sun, H.; Bradley, M.A.; Dupler, E.J.; Giannobile, W.V.; Ma, P.X. Novel antibacterial nanofibrous PLLA scaffolds. J. Control. Release Off. J. Control. Release Soc. 2010, 146, 363-369. [CrossRef] [PubMed]

140. Galler, K.M.; D’Souza, R.N.; Federlin, M.; Cavender, A.C.; Hartgerink, J.D.; Hecker, S.; Schmalz, G. Dentin conditioning codetermines cell fate in regenerative endodontics. J. Endod. 2011, 37, 1536-1541. [CrossRef]

141. Bottino, M.C.; Kamocki, K.; Yassen, G.H.; Platt, J.A.; Vail, M.M.; Ehrlich, Y.; Spolnik, K.J.; Gregory, R.L. Bioactive nanofibrous scaffolds for regenerative endodontics. J. Dent. Res. 2013, 92, 963-969. [CrossRef]

142. Bottino, M.C.; Yassen, G.H.; Platt, J.A.; Labban, N.; Windsor, L.J.; Spolnik, K.J.; Bressiani, A.H.A. A novel three-dimensional scaffold for regenerative endodontics: Materials and biological characterizations. J. Tissue Eng. Regen. Med. 2015, 9, E116-E123. [CrossRef]

143. Piva, E.; Silva, A.F.; Nor, J.E. Functionalized scaffolds to control dental pulp stem cell fate. J. Endod. 2014, 40, S33-S40. [CrossRef]

144. Widbiller, M.; Driesen, R.B.; Eidt, A.; Lambrichts, I.; Hiller, K.A.; Buchalla, W.; Schmalz, G.; Galler, K.M. Cell Homing for Pulp Tissue Engineering with Endogenous Dentin Matrix Proteins. J. Endod. 2018, 44, 956-962. [CrossRef] 
145. Moon, C.Y.; Nam, O.H.; Kim, M.; Lee, H.S.; Kaushik, S.N.; Cruz Walma, D.A.; Jun, H.W.; Cheon, K.; Choi, S.C. Effects of the nitric oxide releasing biomimetic nanomatrix gel on pulp-dentin regeneration: Pilot study. PLoS ONE 2018, 13, e0205534. [CrossRef] [PubMed]

146. Kaushik, S.N.; Kim, B.; Walma, A.M.; Choi, S.C.; Wu, H.; Mao, J.J.; Jun, H.W.; Cheon, K. Biomimetic microenvironments for regenerative endodontics. Biomater. Res. 2016, 20, 14. [CrossRef] [PubMed] 